\title{
Clinical case: From appendicitis to suicide
}

\author{
Olexandr Romaniv ${ }^{1 \mathrm{a}}$, Katherine Pohoriliak $^{\mathrm{a}}$, Margaret Ustyugova ${ }^{\mathrm{a}}$ \\ ${ }^{a}$ Uzhhorod National University, Kyiv, Ukraine
}

\begin{abstract}
Background. For retrospective WHO estimates more and more groups of diseases related to psychosomatic diseases. The clinical case shows the development of psychosomatic diseases and circulation accent patient experiences between somatic and mental suffering, which seriously affects the quality of life and prognosis of health.
\end{abstract}

Keywords: psychosomatics, suicide, attempts, self-destructive, behavior, psychological, diagnostics, obsessive-compulsive, bipolar, depressive, disorder

\section{1. Анамнез життя}

Клієнтка народилась від нормальної вагітності, фізіологічних неускладнених пологів. У психомоторному розвитку від однолітків не відставала. Відвідувала дитячий садок, хворіла не часто, росла здоровою та активною дитиною. В семирічному віці пішла до школи, швидко адаптувалась. За період навчання класи не дублювала, навчальну програму завжди виконувала. Завжди була активною дівчиною, популярною серед ровесників, відмінно вчилась, була старостою класу, організатором різноманітних суспільних заходів. Після закінчення старших класів намагалась вступити на медичний факультет, вирішальним фактором вибору відзначила престижність освіти. Спроба виявилась невдалою, що стало ï першим серйозним життєвим розчаруванням, згадує, що протягом декількох днів постійно плакала. Той же рік вступила на навчання в медичне училище, за спеціальністю «медична сестра», закінчивши яке, влаштувалась на роботу за спеціальністю, але така робота в медицині їй не подобалась, зрозуміла, що ця сфера не для неї, тому звільнилась. Почала працювати в торгівлі. На їі думку, змогла повністю реалізувала себе, робота приносила задоволення та значний прибуток, хоча була складною, іноді виснажливою. Відмічає, що були такі моменти, коли вона так багато працювала, що зараз, ретроспективно оцінюючи дані записника, не розуміє, як вона справлялась 3 такою кількістю справ водночас з турботою про дітей, батьків, чоловіка.

${ }^{1}$ C Romaniv O, Pohoriliak K, Ustyugova M, 2017. This article is distributed under the terms of the Creative Commons Attribution License, which permits unrestricted use and redistribution provided that the original author and source are credited.
Сімейний анамнез: дані про батька відсутні, він помер, коли клієнтці не було року. Свою матір пам'ятає як особу, яка любила перебувати в центрі уваги, потребувала уважного відношення до себе, особливо протягом останніх півроку, тоді піклувалась про неї, доглядала через хворобу. Дуже близькою людиною в сім'ї була їі старша сестра, їхні стосунки характеризує як підтримуючі, дружні. Психопатологічно ускладнена спадковість. Клієнтка розповіла також про племінника, якого дуже любить, розповіла про наявні в нього серйозні проблеми психічного здоров'я, через які сильно турбується. Описала наявність невідчепних думок тривожного змісту про стан здоров'я племінника та взаємозв'язок з її власним станом здоров'я, способом життя. Клієнтка оцінила думки як продукт власної свідомості, які неможливо ігнорувати. Повідомила, що для полегшення цих переживань намагалась ігнорувати рідну сестру та племінника, не запрошувала їх в гості, не відповідала на дзвінки. Разом з тим відчувала провину за власні думки та дії.

Особистий анамнез:з 14 років почались місячні. За пару днів до них відмічала коливання настрою, роздратування, плаксивість. Місячні були регулярними та безболісними. Вперше вийшла заміж в 20 років по закоханості. Перед весіллям була діяльною, багатослівною, мало спала, готувалась до весілля, мріяла про майбутнє. Подібний стан тривав протягом півроку після весілля. Згодом дізналась про власну вагітність. Після народження здорового доношеного хлопчика, емоційний стан з часом змінився: з'явилась в'ялість, плаксивість, дратівливість, порушився сон, знизився апетит. Клієнтка пов'язала вищеописане з перевтомою, турботами про новонародженого, проблемами в особистих стосунках з чоловіком. До лікарів не зверталась, емоційний 
фон нормалізувався поступово самостійно. Після дворічного шлюбу з чоловіком розлучились «через відсутність спільних інтересів», в подальшій розмові натякала на його невідповідну поведінку та проблеми з алкогольними напоями. 10 років тому повторно вийшла заміж, стосунки з чоловіком протягом тривалого часу були дружніми, об'єднували спільні цілі та інтереси. Від шлюбу народила дівчинку. Вагітність, пологи, післяпологових період протікали без виражених афективних коливань. За її словами, відчувала задоволення, незважаючи на певні труднощі, «певно вже була більш зрілою».Також вона розповіла, що після вагітності їй була діагностовано ерозію шийки матки. Результат цитологічного дослідження виявився незадовільним, проведена екстирпація матки з придатками зі збереженням гормональної функції. Клієнтка висловила розчарування $з$ цього приводу так, як хотіла третю дитину.

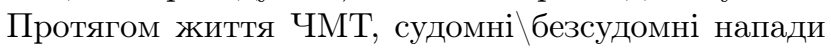
не спостерігались. Дитячі інфекції: вітряна віспа, кір. В анамнез - папіломавірусна інфекція. Хворобу Боткіна, туберкульоз заперечує. Шкідливі звички заперечує, досвід вживання наркотичних речовин заперечує. Алергологічний анамнез не обтяжений.

\section{2. Анамнез захворювання}

Останнім часом проживали з чоловіком «на відстані» через роботу. Клієнтка сильно виснажувалась, поєднуючи ведення бізнесу та виховання дітей. На початку 2016 року запускала новий проект, тижні перебувала на роботі. Почала спостерігати проблеми зі сном, харчувалась нерегулярно, виконувала значні розумові та фізичні навантаження. У кінці лютого відзначила загальне нездужання, 3 клінічною картиною гострого апендициту була госпіталізована та прооперована в умовах хірургічного відділення. Отримала курс антибіотикотерапії. Зі слів клієнтки, операція виявилось необгрунтованою, а наслідки оперативного лікування були важкими, проявились симптомами шлунковокишкових розладів, таких як: відсутність апетиту, часте блювання, болі у шлунку, спастичний коліт, проноси, що привело до вираженого зневоднення, інтоксикації. Такий стан тривав приблизно два місяці і привів до значного виснаження, клієнтка схудла на 10 кг, IMT становив 19.5, відчувала виражену загальну слабкість, значну стомлюваність від найменших дій. Клієнтка припинила займатись власною справою, передала обов'язки чоловіку. Соматичні проблеми значно вплинули на iï психічне здоров'я: а саме, проблеми зі сном, настрій погіршився, життя приносило значно менше задоволення, виникла тривога за власне здоров'я, нав'язливі думки про необхідність дотримання дієти сформували ритуали поведінки, які проявились скурпульозним підбором продуктів харчування, приготування їжі, з харчуванням за чітким графіком з чітко відміреними дозами продуктів. Це значно впливало на
111 якість життя - обтяжувало побутові справи та займало робочий час, викликали сварки з чоловіком, заважало відпочинку з родиною на морі. 3 цими проблемами клієнтка звернулась до невропатолога, який призначив ій тразадон в дозі 50 мг \д, прийняла препарат одноразово, з її слів сон покращився, а з іншими проблемами вона вирішила справлятись самостійно немедикаментозними засобами, просто обдумовуючи свої проблеми та позитивно знаходячи з них вихід. Але подібне життя стало обтяжливим, соматичні симптоми ставали менш вираженим, а психічна напруга навпаки підвищувалась, відповідні вищеописані симптоми стали нестерпними, періодично виникали спочатку несформовані думки про самогубство, які поступово переросли в ідеї, як саме це здійснити. За словами чоловіка, його жінка неодноразово в сварках погрожувала покінчити 3 життям. Після однієї з серйозних сімейних сварок, таємно від чоловіка зібрала психотропні препарати, що були вдома, автомобілем від'іххала за 30 км від міста, заховалась та прийняла велику кількість таблеток. Прийшла до себе вже в реанімації. Психіатру та близьким не описала свій вчинок «одномоментною необдуманою імпульсною дією».

\section{3. Психоневрологічний статус}

На первинному прийомі у психіатра відмітила пригнічений настрій та відсутність зацікавленості в речах, які раніше приносили насолоду, брак енергї зранку, швидкоплинні ідеї самозвинувачення, схуднення, що пов'язувала із «зневодненням», періодичними порушенням сну у вигляді утрудненого засинання,більшу частину часу, протягом останніх 6 місяців. Також відзначила неприємні думки.

Психічний стан на візиті: у свідомості. Зовнішньо виглядала охайно, вираз обличчя засмучений, напружений. Постава скована, рухи сповільнені. Мовному контакту доступна. В часі, просторі та власній особі орієнтована правильно. Скарги висловлює самостійно. Мислення сповільнене за темпом, судження песимістичні. Наявність розладів сприйняття заперечила, поведінкою не виявляла. Фон настрою знижений, відмічала вечірні добові коливання. Емоційнійні реакції лабільні. Інтелектуально-мнестичні функції не порушені. Вольові потяги послаблені. Суӥцидальні думки на момент огляду заперечила, непереконливо. Розповіла про суїцидальну спробу шляхом отруєння медикаментами, яку скоїла близько тижня тому. Критика до свого стану обмежена.

Сомато-неврологічний стан: зріст вище середнього, зниженої вгодованості. Шкіра та видимі слизові чисті, блідо-рожеві. Язик вологий, не обкладений. ЩЗ та л/в в нормі. Над легенями - дихання везикулярне, хрипи не прослуховуються. Серце - діяльність ритмічна, тони чисті, звучні. АТ-130/80 мм.рт.ст. ps 72 уд \хв. Живіт м'який, безболісний при пальпації. С-м Пастернацького від'ємний білатерально. Периферичні набряки від- 
сутні. Неврологічно: обличчя симетричне, зіниці $\mathrm{D}=\mathrm{S}$, рух очних яблук в повному об'ємі, фотореакції жваві. Сухожилкові та періостальні рефлекси без особливостей. Менінгеальних ознак та вогнищевої неврологічної симптоматики не виявлено. В позі Ромберга стійка.

\section{4. Психодіагностичне обстеження}

За опитуванням M.I.N.I.виповнюються критерії поточного великого депресивного епізоду; поточної суїцидальності. Зустрічаються критерії обсесивнокомпульсивного розладу. Психотичні розлади та розлади настрою з психотичними ознаками категорично заперечувала. Ліссофобія.

За опитуванням MADRS - 32 бали, важка депресія.

За шкалою YMRS - 2б.

C-SSRS - показала наявність впродовж життя суїцидальної активності та дозволила отримати уявлення про важкість та серйозність даної спроби.

MМРI:Кодування за Уєлшу: 1"8'732-64/50:9\# FKL/Заключення: профіль достовірний. Іпохондричнодепресивний синдром у акцентуйованої особистості за змішаним типом з рисами психастенічної та істероїдної особистостей.

TAT: Відношення до себе характеризується високим рівнем особистісних та соціальних потреб, відповідність встановленому ідеалу зовнішності жінки (Жінка має бути гарною, з зачіскою та макіяжем). Важливі теми - сімейне та інтимне благополуччя, особистісний ріст. Критичні зони - нав'язливі думки (почуття вини та самозвинувачення, через невідповідність встановленому ідеалу); переживання 3 фізичних станів; відносини в сім'ї, суїцидальні переживання. Картина світу досліджуваної - реалістичне відношення до праці та життевих досягнень, чітка потреба в турботі про близьких, в інтимній сфері важлива спільність інтересів, взаємозацікавленість, взаємопідтримка, переживання спільних проблем, які об'єднують.

\section{5. Діагноз та його обгрунтування}

В роботі $з$ клієнткою на основі ї̈ скарг, анамнезу життя та захворювання були відмічені критерії біполярного розладу та обсесивно-компульсивного розладу. Критеріями діагнозу біполярного розладу стали описані клієнткою короткочасні періоди гіпоманії перед весіллям і періодично повторювались та наявний зараз поточний депресивний епізод. Критеріями діагнозу Обсесивно-компульсивного розладу стали описані нею невідчепні переживання щодо стану свого власного здоров'я, стану здоров'я племінника, описані нею та їі рідними дії та ритуали, які вона здійснювала для полегшення переживань. Використання діагностичних критеріїв класифікації MKX-10 є достатніми для постановки діагнозу, але для їх доказовості були застосовані психодіагностичні інструменти. Деякі з них допомогли не лише відзначити критерії та в цілому природу захворювання, але і зрозуміти саму особу, механізми психіки та їх взаємодію з патологічними симптомами. Оцінка показників суїцидальних думок, їх інтенсивність та частота, наявність обдуманого способу здійснення суїциду та здійснена невдала суїцидальна спроба свідчать про надзвичайну серйозність суїцидальної поведінки в клієнтки, що реально та потенційно загрожувала їі життю, а також складає серйозний ризик повторення спроби в майбутньому.

Діагноз: Біполярний афективний розлад, поточний епізод тяжкої депресіі, без психотичних симптомів. Обсесивно-компульсивний розлад, змішані обсесивні думки та дії. Навмисне самоотруєння з використанням седативно-снодійних, психотропних препаратів

\section{6. Стратегія лікування}

Препаратами вибору в даному випадку було обрано кветіапін 400мг \д, літій карбонат 600мг \д. Ефективність лікування депресивно-тривожної симптоматики та суїцидальних тенденцій даними препаратами, доведена в міжнародних клінічних дослідженнях і перевірена власним досвідом.

3 другого тижня лікування стан клієнтки поступово покращився, а саме: нормалізувався сон, знизився рівень тривоги. На прийомі клієнтка скаржилась на загальну слабкість, апатію, неприємні думки, але менше емоційне наповнення даних переживань. На контролі в психіатра через місяць відмітила відновлення працездатності та повернення зацікавленості в діяльності. Через два місяці більш детально змогла описати власні переживання, повідомила про намагання «завжди бути кращою у всьому» та напругу, пов'язану з цими переконаннями. Було рекомендовано довготривалу психотерапію.

\section{7. Підсумовуючи описаний клінічний випадок можна зробити наступні висновки}

Контекст скоєння суїцидальної спроби становила сукупність факторів простежених анамнестично, даних клінічного інтерв'ю та психодіагностики. Психопатологія грає важливу роль в багатьох випадках суӥциду, а даний клінічний випадок чітко це ілюструє.

1. Наявність психічного захворювання (афективного розладу) підвищуе ризик суӥциду; за даними досліджень збільшення ризику на $15 \%<1>$. Анамнестично підтверджені періоди гіпоманії 3 реалізацією продуктивних проектів створили фон вираженої напруги та психічного виснаження. Довготривалий важкий депресивний епізод клієнтки був ускладнений вираженими соматичними проблемами, які, варто відмітити, не мали обгрунтованих доказово причин. 
2. Клієнтка на свій вік виглядає молодою, має молодшого чоловіка, двох дітей підлітків, успішно керує власним бізнесом, є особою стенічною, демонстративною, з високим рівнем вимог до себе, з постійним самоконтролем, та схильністю до відчуття вини через невідповідність цим вимогам. Такий «спосіб» є типовим для молодої жінки, яка звикла бути сильною і не дозволить показати слабкість як собі, так близьким.

3. Очевидним є психосоматичний маніфест, як перший сигнал аутоагресії, так і психічний механізм «виходу» напруги, який став заключною ланкою в порочному колі психічна напруга - психічне виснаження - соматичне виснаження - фрустрація через неспроможність - психічна напруга.

4. Клієнтка обрала стратегію пасивного уникнення контакту з навколишньою проблемною дійсністю.

\section{8. Додаткова інформація}

\section{1. Конфлікт інтересів}

Автори заявляють про відсутність конфлікту інтересів.

\section{References}

1. Bostwick J, Pankratz V. Affective disorders and suicide risk: a reexamination. Am J Psychiatry 2000;157(12):1925-32. doi 10 . 1176/appi.ajp.157.12.1925 